\title{
Informing professional practice: (Future) Teachers' choice, use, and evaluation of (non-)scientific sources of educational topics
}

\author{
Eva Thomm¹, Eva Seifried², and Johannes Bauer ${ }^{1}$ \\ 'Faculty of Education, University of Erfurt, Erfurt, Germany \\ ${ }^{2}$ Department of Psychology, Heidelberg University, Heidelberg, Germany
}

\begin{abstract}
Understanding processes of selecting, evaluating, and using relevant information sources to inform oneself about scientific topics, that is, sourcing, is a current topic within educational psychology. This special issue combines recent research about sourcing with a particular focus on its role in the reception of educational research by (future) teachers. Recent debates about standards of teacher professionalism emphasize that teachers should be able to inform and justify their professional actions and decisions on the basis of scientific evidence. Thus, sourcing is an essential competence in retrieving and using relevant research knowledge. The contributions of this special issue shed light on different processes, requirements, and consequences of sourcing in the context of teacher education and teachers' work. They study potential factors and criteria that may affect teachers' selection, evaluation, and use of (non-)scientific information sources even in the pre-service stage of their development. Moreover, the studies analyze the impact of source preferences and accessibility of scientific sources on pre-service and in-service teachers' conceptions of educational topics and perceptions of educational research knowledge. Together with the two subsequent critical discussions, the contributions of this special issue point to challenges and obstacles that research usage by teachers and its preparation in teacher education face.
\end{abstract}

Keywords: Sourcing, teachers, teacher education, scientific reasoning, evidence-based practice

Informationen für die professionelle Praxis: Wie (angehende) Lehrkräfte (nicht-)wissenschaftliche Informationsquellen zu Bildungsthemen wählen, nutzen und bewerten

Zusammenfassung: Ein aktuelles Forschungsanliegen der Pädagogischen Psychologie ist es, ein Verständnis darüber zu gewinnen, wie Informationsquellen ausgewählt, bewertet und genutzt werden, um sich über wissenschaftliche Themen zu informieren; dies wird als Sourcing bezeichnet. Dieses Themenheft bündelt aktuelle Forschung zum Thema Sourcing, mit einem besonderen Fokus auf dessen Rolle in der Rezeption bildungswissenschaftlicher Befunde durch (angehende) Lehrkräfte. Diskussionen um Standards der Lehrerprofessionalität betonen, dass Lehrkräfte fähig sein sollen, ihre Handlungen und Entscheidungen auf der Grundlage von wissenschaftlichen Erkenntnissen zu informieren und zu begründen - somit stellt Sourcing eine grundlegende Kompetenz dar, um relevantes, wissenschaftliches Wissen heranziehen und nutzen zu können. Die Beiträge dieses Themenhefts beleuchten verschiedene Prozesse, Voraussetzungen und Konsequenzen von Sourcing im Kontext der Lehrerbildung und der Arbeit von Lehrkräften. Hierbei werden erstens potenzielle Faktoren und Kriterien betrachtet, die bereits die Auswahl, Bewertung und Nutzung von (nicht-)wissenschaftlichen Informationsquellen von Lehramtsstudierenden beeinflussen können. Zweitens wird in den Studien der Einfluss von Quellenpräferenzen sowie der Zugänglichkeit wissenschaftlicher Quellen auf die Annahmen von (angehenden) Lehrkräften über spezifische Bildungsthemen sowie auf ihre Wahrnehmung von Bildungsforschung analysiert. Zusammen mit den zwei sich anschließenden kritischen Diskussionen weisen die Beiträge auf Herausforderungen und Hindernisse hin, die sich in der Lehrerbildung stellen, um die Nutzung wissenschaftlicher Informationsquellen durch (angehende) Lehrkräfte zu fördern.

Schlüsselwörter: Sourcing, Lehrkräfte, Lehrerbildung, Wissenschaftliches Denken, Evidenzbasierte Praxis 


\section{Sourcing of educational research knowledge by (future) teachers}

According to policy calls, teachers shall be equipped to inform and reflect their professional practice on the basis of knowledge of educational research ${ }^{1}$ (e.g., Bauer \& Prenzel, 2012; Brown \& Zhang, 2016; European Commission [EC], 2007; Kultusministerkonferenz [KMK], 2004, 2019; Slavin, 2002). This implies valuing scientific evidence that is grounded in established theory and derived by reliable methods, and acquiring competencies to find, read, and understand research findings in education (Bauer, Berthold, Hefter, Prenzel \& Renkl, 2017; Niemi, 2008). Serving as orienting knowledge and potential corrective, educational research knowledge shall thereby extend teachers' professional resources and complement, though not replace, their individual expertise and experiences in order to improve and add innovation to their professional practice (Bauer, Prenzel \& Renkl, 2015; Rousseau \& Gunia, 2016; Stark, 2017).

However, teachers rarely engage in research reception (e.g., Brown \& Zhang, 2016; Dagenais et al., 2012; HemsleyBrown \& Sharp, 2003; Hetmanek et al., 2015). Instead, both in-service and pre-service teachers seem to rely heavily on common practices, everyday theories, and experiential knowledge. For instance, Williams and Coles's (2007) survey showed that teachers mostly named other colleagues and informal discussions as sources for retrieving information on teaching theory and practices, while referring to research journals least often. Bråten and Ferguson (2015) found that pre-service teachers endorsed experiential, practice-based sources of knowledge (e.g., personal experiences, observations of fellow teachers) rather than theorybased sources (e.g., textbooks, research articles, and professional literature) when assessing the relevance of sources for knowledge about instruction and student learning.

Potential reasons for (future) teachers' non-reception of educational research are manifold. Characteristics of research production and the resulting knowledge, lack of or failures in mechanisms of transfer as well as dysfunctional attitudes and the lack of competences on the part of the (future) teachers have been discussed in the literature (Bromme, Prenzel \& Jäger, 2014; van Schaik, Volman, Admiraal \& Schenke, 2018). For example, (future) teachers are found to take critical stances toward the usefulness and practical relevance of educational research (e.g., Joram, Gabriele \& Walton, 2020). Moreover, they frequently demonstrate only insufficient skills to refer to and reason along with research findings or report low expectations of their capacities to do so (e.g., Duke \& Ward, 2009; van
Schaik et al., 2018). Therefore, a number of studies have investigated interventions to raise pre-service teachers' competences in research usage (Klein, Wagner, Klopp \& Stark, 2015; Wenglein, Bauer, Heininger \& Prenzel, 2015).

However, even if (future) teachers are equipped with such competences, they still face stark barriers to using educational research. As one of the very first steps in research reception, (future) teachers need to search and access valid research information that is relevant to their profession-related problems. Therefore, the question about how (future) teachers draw on or engage with research knowledge is inextricably tied to the question of which information sources they can actually turn to and consult. Especially after leaving the university, they often lack direct access to information sources providing original research findings and knowledge or trustworthy compilations (e.g., Farley-Ripple, May, Karpyn, Tilley \& McDonough, 2018; Ratcliffe et al., 2005). Hence, they must locate and identify this information across and within various information sources (Davies, 1999; Duke \& Ward, 2009). Moreover, limits in time resources to search for research and exhaust relevant sources remain major obstacles. Given the mentioned constraints, teachers will most likely turn to free and easily accessible web searches rather than to scientific libraries or databases. Thus, besides basic skills in critical thinking and scientific reasoning, competences in sourcing are essential for (future) teachers to engage with research knowledge in education during and beyond teacher training.

Understanding processes of selecting, evaluating, and using relevant information sources to inform oneself about scientific matters is a current topic of educational psychology, for instance, in research on reading, multiple source use, argumentation, scientific reasoning, and epistemic cognition (e.g., Barzilai \& Chinn, 2020; Braasch, Bråten \& McCrudden, 2018; Bråten, Stadtler \& Salmerón, 2018; Bromme \& Goldman, 2014; Perfetti, Rouet \& Britt, 1999; Tabak, 2016). Sourcing describes a set of competences in attending to, evaluating, and using characteristics of information sources in order to select relevant information and assess the reliability of the retrieved contents (e.g., Bråten et al., 2018; Bromme, Stadtler \& Scharrer, 2018; Wineburg, 1991). Such source characteristics include, for example, authors' credentials and the type of publication or publication genre (Braasch et al., 2018), and serve as "anticipatory frameworks" (Wineburg, 1991, p.79) allowing individuals to predict or assume what kind of information they may receive. Sourcing strategies help individuals "to focus information processing efforts on information that is reliable and from more credible sources, and to actively scrutinize, 
disregard or actively refute information that is less reliable or from less credible sources" (Braasch et al., 2018, p.3).

For these reasons, sourcing is a gatekeeper competence in the retrieval and use of research knowledge. A lack of skills in finding and using relevant sources may prevent individuals from using scientific information sources at all, even given functional attitudes and beliefs about the value of research knowledge. This also pertains to research reception in education by (future) teachers and gains in significance considering that they may judge non-scientific sources to be the more reliable and accessible ones (Landrum, Cook, Tankersley \& Fitzgerald, 2002; van Schaik et al., 2018). Admittedly, (future) teachers sometimes hardly have any other option than to rely on non-scientific sources, because research does not provide a sufficient amount of evidence for every topic in the same manner. However, even in this case, sourcing skills may contribute to allowing (future) teachers to evaluate the available information critically and weigh its potential benefits and shortcomings.

Shedding light on sourcing in pre-service and in-service teachers can therefore help us to understand preferences and usage of both scientific and non-scientific sources, to identify potential factors that may crucially affect sourcing processes, and, hence, to inform corresponding training measures to foster sourcing competences during teacher education. Researchers have often subsumed sourcing capacities within broader concepts such as information literacy, scientific literacy, or educational research literacy (Duke \& Ward, 2009; Groß Ophoff, Wolf, Schladitz \& Wirtz, 2017; Niemi, 2008). Also, process models of evidence-based practice that describe the steps and associated competences necessary to use research knowledge successfully have highlighted sourcing activities, such as searching, identifying, and retrieving relevant information across and within various information sources (Davies, 1999; Ramos, Schafer \& Tracz, 2003; Rubin, 2008; Wenglein et al., 2015). However, although considered important, studies have primarily focused on examining the ways in which (future) teachers appraise and use research knowledge and how skills necessary for knowledge utilization can be fostered (e.g., Joram et al., 2020; Stark, 2017; Trempler et al., 2015; Wenglein et al., 2015). Paying similar attention to facets and processes of sourcing will extend our understanding of the full range of processes underlying research reception in education.

\section{Introduction to}

\section{the empirical contributions}

The bodies of research on sourcing, on the one hand, and on (future) teachers' reception of educational research, on the other hand, have so far been largely disconnected. However, there is growing interest in this topic (e.g., Bråten \& Ferguson, 2015; List \& Du, 2020; Merk, Rosman, Rueß, Syring \& Schneider, 2017; Thomm, Gold, Betsch \& Bauer, 2021). This special issue aims to connect these lines of research and highlights studies that examine sourcing with a particular focus on its role in teacher education. It presents five empirical contributions, which are complemented by two critical discussions written by Leila Ferguson and Frank Fischer. All empirical contributions investigate sourcing with regard to scientific information sources (scientific literature, academic textbooks, researchers, etc.) by pre-service or in-service teachers. By addressing different processes (i.e., selection, evaluation, and / or use of sources), requirements, and potential consequences of sourcing, together, they draw a rich portrait of (future) teachers' sourcing behavior.

The first three studies of the special issue examine potential factors and criteria that may influence pre-service teachers' selection, evaluation, and use of scientific and non-scientific information sources. The authors provide a differentiated perspective on pre-service teachers' beliefs about the instrumental value of educational research as well as of experiential knowledge and its impact on sourcing processes, shed light on the role of pre-service teachers' epistemic aims to consult scientific and non-scientific sources, and analyze criteria that pre-service teachers apply to select information on educational topics from online sources.

Kiemer and Kollar (2021) examined pre-service teachers' beliefs about the utility of educational research, subjective theories, and anecdotal evidence in order to resolve a problematic classroom situation and shed light on preservice teachers' selection and subsequent use of scientific sources (i.e., educational theory, educational research) and non-scientific sources (i.e., subjective theory, anecdotal evidence) to inform their solution. Their results underscore the point that pre-service teachers ascribed higher utility to anecdotal evidence than to educational research, which was also mirrored in their source selection. In particular, when pre-service teachers saw practical value in educational research, they were more inclined to consult and use scientific sources. This study contributes to the differentiation of pre-service teachers' assumptions about the diverse types of knowledge they refer to and underlines the relevance of favorable beliefs toward the instrumental value of research knowledge in order to foster preservice teachers' consideration of scientific sources.

Hendriks, Seifried and Menz (2021) investigated the hypothesis that (pre-service) teachers' perceptions of scientific and experiential sources may depend on their epistemic aim (i.e., their goal or purpose). The results indeed demonstrated that pre-service teachers assessed the trustworthiness of a scientific source (i.e., a researcher) and an 
experiential source (i.e., an experienced teacher) adaptively: When aiming for a theoretical explanation about schooling and teaching, a researcher was judged to have more expertise and integrity but less benevolence than experienced teachers. Conversely, when aiming for practical tips for everyday school life, an experienced teacher was considered to have more expertise, integrity, and benevolence than researches. The authors suggest that pre-service teachers may generally opt for practical rather than theoretical knowledge, which may bias their preference of non-scientific over scientific sources. Although such generalized preferences remain barriers, these findings are encouraging, as they suggest that, for specific goals, pre-service teachers may at least consider scientific sources to provide them with trustworthy and pertinent information.

The study by Zimmermann and Mayweg-Paus (2021) provides insight into how pre-service teachers may actually search for educational information online. The authors scrutinized whether and to what extent pre-service teachers refer to and reflect about characteristics of information content, the information provider, and the type of media when selecting relevant, authentic websites. As a very first intervention, they tested whether critical reflection about such criteria could be enhanced through collaborative reasoning (in comparison to individual reasoning). Overall, only one third of selected websites were revealed to be indeed science-related. Participants who collaboratively reasoned about their selection of relevant websites provided more elaborate reasoning about the criteria they had applied than participants who searched individually for information. However, there were no differences between participants' references to the different types of criteria. In general, participants referred mostly to characteristics of the information, while they rarely mentioned characteristics of the information provider. Although collaborative reasoning led to more reasoned choices, the findings support the observations that pre-service teachers often turn to sources other than scientific ones (e.g., Bråten \& Ferguson, 2015)-and that even university students may attend only infrequently to informative source characteristics (e.g., Barzilai, Tzadok \& Eshet-Alkalai, 2015).

Two further articles of this special issue extend the perspectives presented so far by highlighting the conclusion that source preferences as well as source accessibility may also in turn affect the assumptions and beliefs that (future) teachers derive, maintain, and draw on to justify judgments and actions (see Braasch et al., 2018). These studies focus on the impact of source preferences and source access on (future) teachers' (mis)conceptions of educational topics on the one hand and their perceptions of educational research knowledge on the other hand.

Menz, Spinath and Seifried (2021) connected pre-service teachers' endorsement of educational psychological miscon- ceptions with their reference to non-scientific anecdotal sources or scientific sources. The authors found that pre-service teachers based their beliefs about educational psychological topics-whether adequate or questionable-more on sources providing anecdotal rather than scientific evidence. Moreover, pre-service teachers who primarily sourced from anecdotal evidence were found to endorse more misconceptions and were less susceptible to refutations through empirical evidence than pre-service teachers who primarily sourced from scientific evidence. However, such sourcing preferences did not lead participants to question the potency of research to examine educational topics. While the latter result may be reassuring, the study provides indications that source preferences can result in higher numbers of misconceptions and possibly hinder correction of misconceptions through established interventions such as refutations.

Thomm, Sälzer, Prenzel and Bauer (2021) considered in-service teachers' access to scientific sources, their perceived skill and time for exhausting such sources, and their familiarity with basic concepts of research methods as basic requirements for research reception. Drawing on a large sample of teachers surveyed in PISA 2012 (Germany), the authors explored in what ways these conditions may affect teachers' appreciation of evidence-based practice and the perceived irrelevance of research knowledge. Contrary to prior reports, the surveyed teachers did not endorse overly negative views of evidence-based practice and educational research. However, the authors found that mere source access did not facilitate favorable stances toward educational research. In particular, a perceived lack of one's own skills and time resources for searching for and identifying relevant information across and within scientific sources appeared to go hand in hand with judging research findings irrelevant. The results emphasize the importance of strengthening (future) teachers' sourcing capacities alongside existing efforts to increase the availability of educational research knowledge, for example through clearing houses (see Seidel et al., 2017).

In sum, the present contributions underscore the significance of both skills in finding, evaluating, and using relevant scientific information sources and favorable beliefs about the epistemic and instrumental value of research knowledge for (future) teachers' reception of educational research. The empirical studies complement each other in identifying potential challenges and obstacles that teacher education has to face in order to promote consideration and usage of scientific information sources. Thus, they demonstrate that increasing the availability of scientific sources, though doubtless a fundamental requirement, may not necessarily increase its usage or diminish doubts about the relevance of educational research findings for professional practice (see also Hetmanek et al., 2015). We believe, however, that research on (future) teachers' sourcing and re- 
search usage should move on to pay more attention to the diverse patterns of epistemic and utilitarian aims for which (future) teachers might consider consulting scientific sources. This would contribute to a deeper understanding of the circumstances under which educational research knowledge is attractive and actually helpful to teachers. Yet, and finally, research reception may only occur when (future) teachers also possess competences relevant for sourcing of scientific information in particular - and also apply them. Generalized source preferences and a perceived lack of relevant sourcing skills could hamper acquisition of accurate knowledge relevant to one's practice and undermine appreciation of educational research. Fostering relevant sourcing competences equips pre-service and in-service teachers not solely to rely on non-scientific sources, but to benefit from a broader array of professional resources, including systematically derived research knowledge.

\section{References}

Barzilai, S. \& Chinn, C. A. (2020). A review of educational responses to the "post-truth" condition: Four lenses on "post-truth" problems. Educational Psychologist, 55(3), 107 - 119. https://doi.org/ 10.1080/00461520.2020.1786388

Barzilai, S., Tzadok, E. \& Eshet-Alkalai, Y. (2015). Sourcing while reading divergent expert accounts: Pathways from views of knowing to written argumentation. Instructional Science, 43(6), 737 - 766. https://doi.org/10.1007/s11251-015-9359-4

Bauer, J., Berthold, K., Hefter, M. H., Prenzel, M. \& Renkl, A. (2017). Wie können Lehrkräfte und ihre Schülerinnen und Schüler lernen, fragile Evidenz zu verstehen und zu nutzen? [How can teachers and students learn to understand and use fragile evidence?]. Psychologische Rundschau, 68(3), 188-192. https:// doi.org/10.1026/0033-3042/a000363

Bauer, J. \& Prenzel, M. (2012). European teacher training reforms. Science, 336, 1642 - 1643. https://doi.org/10.1126/science.1218387

Bauer, J., Prenzel, M. \& Renkl, A. (2015). Evidenzbasierte Praxis im Lehrerberuf?! Einführung in den Thementeil [Evidencebased practice - in teaching?! Introduction to the special issue]. Unterrichtswissenschaft, 43(3), 188-192. https://doi. org/10.3262/UW1503188

Braasch, J. L. G., Bråten, I. \& McCrudden, M. T. (2018). Introduction to research on multiple source use. In J. L. G Braasch, I. Bråten \& M. T. McCrudden, M. T. (Eds.), Handbook of multiple source use (pp. 1 -13). New York: Routledge.

Bråten, I. \& Ferguson L. E. (2015). Beliefs about sources of knowledge predict motivation for learning in teacher education. Teaching and Teacher Education, 50, 13-23. https://doi. org/10.1016/j.tate.2015.04.003

Bråten, I., Stadtler, M. \& Salmerón, L. (2018). The role of sourcing in discourse comprehension. In M. F. Schober, D. N. Rapp \& M. A. Britt (Eds.), The Routledge handbook of discourse processes (2nd ed., pp. 141 -166). New York: Routledge.

Bromme, R. \& Goldman, S. (2014). The public's bounded understanding of science. Educational Psychologist, 49, 59 - 69. https://doi. org/10.1080/00461520.2014.921572

Bromme, R., Prenzel, M. \& Jäger, M. (2014). Empirische Bildungsforschung und evidenzbasierte Bildungspolitik: Eine Analyse von Anforderungen an die Darstellung, Interpretation und Re- zeption empirischer Befunde. [Educational research and evidence based practice policy - The challenge of exposing and of understanding educational research.] Zeitschrift für Erziehungswissenschaft, Sonderheft 27, 3-54. https://doi.org/10. 1007/s11618-014-0514-5

Bromme, R., Stadtler, M. \& Scharrer, L. (2018). The provenance of certainty: Multiple source use and the public engagement with science. In J. L. G. Braasch, I. Bråten \& M. T. McCrudden (Eds.), Handbook of multiple source use (pp. 269 - 284). New York, NY: Routledge.

Brown, C. \& Zhang, D. (2016). Is engaging in evidence-informed practice in education rational? What accounts for discrepancies in teachers' attitudes towards evidence use and actual instances of evidence use in schools? British Educational Research Journal, 42(5), 780-801. https://doi.org/10.1002/ berj.3239

Dagenais, C., Lysenko, L., Abrami, P. C., Bernard, R. M., Ramde, J. \& Janosz, M. (2012). Use of research-based information by school practitioners and determinants of use: A review of empirical research. Evidence \& Policy: A Journal of Research, Debate and Practice, 8(3), 285-309. https://doi.org/10.1332/174426412X 654031

Davies, P. (1999). What is evidence-based education? British Journal of Educational Studies, 47(2), 108-121. https://doi.org/ 10.1111/1467-8527.00106

Duke, T. S. \& Ward, J. D. (2009). Preparing information literate teachers: A metasynthesis. Library \& Information Science Research, 31(4), 247 - 256. https://doi.org/10.1016/j.lisr.2009.04.003

European Commission. (2007). Towards more knowledge-based policy and practice in education and training. Retrieved from https:// op.europa.eu/en/publication-detail/-/publication/962e3b89c546-4680-ac84-777f8f10c590/language-en

Farley-Ripple, E., May, H., Karpyn, A., Tilley, K. \& McDonough, K. (2018). Rethinking connections between research and practice in education: A conceptual framework. Educational Researcher, 47(4), 235-245. https://doi.org/10.3102/0013189X18761042

Groß Ophoff, J., Wolf, R., Schladitz, S. \& Wirtz, M. (2017). Assessment of educational research literacy in higher education: Construct validation of the factorial structure of an assessment instrument comparing different treatments of omitted responses. Journal for Educational Research Online, 9(2), 37 - 68.

Hemsley-Brown, J. \& Sharp, C. (2003). The use of research to improve professional practice: A systematic review of the literature. Oxford Review of Education, 29(4), 449-471. https://doi. org/10.1080/0305498032000153025

Hendriks, F., Seifried, E. \& Menz, C. (2021). Unraveling the „smart but evil“" stereotype: Pre-service teachers' evaluation of educational psychology researchers versus teachers as sources of information. Zeitschrift für Pädagogische Psychologie, 35(2 - 3), 157 - 171. https://doi.org/10.1024/1010-0652/a000300

Hetmanek, A., Wecker, C., Kiesewetter, J., Trempler, K., Fischer, M. R., Gräsel, C. et al. (2015). Wozu nutzen Lehrkräfte welche Ressourcen? Eine Interviewstudie zur Schnittstelle zwischen bildungswissenschaftlicher Forschung und professionellem Handeln im Bildungsbereich [For what do teachers use which kind of resources? An interview study on the interface between research and professional practice in education]. Unterrichtswissenschaft, 43(3), $193-208$.

Joram, E., Gabriele, A. J. \& Walton, K. (2020). What influences teachers' "buy-in" of research? Teachers' beliefs about the applicability of educational research to their practice. Teaching and Teacher Education, 88, 102980. https://doi.org/10.1016/j. tate.2019.102980

Kiemer, K. \& Kollar, I. (2021). Source selection and source use as a basis for evidence-informed teaching: Do pre-service teachers' beliefs regarding the utility of (non-)scientific information sour- 
ces matter? Zeitschrift für Pädagogische Psychologie, 35(2 - 3), 127 - 141. https://doi.org/10.1024/1010-0652/a000302

Klein, M., Wagner, K., Klopp, E. \& Stark, R. (2015). Förderung anwendbaren bildungswissenschaftlichen Wissens bei Lehramtsstudierenden anhand fehlerbasierten kollaborativen Lernens: Eine Studie zur Replikation und Stabilität bisheriger Befunde und zur Erweiterung der Lernumgebung. [Fostering of applicable pedagogical knowledge in student teachers by collaborative error-based learning: A study on the replicability and stability of previous results and an expansion of the learning environment.] Unterrichtswissenschaft, 43(3), 225-244.

Kultusministerkonferenz [KMK] (2004, 2019). Standards für die Lehrerbildung: Bildungswissenschaften [Standards of Teacher Education: Educational Sciences]. Berlin. Retrieved from https: //www.kmk.org/fileadmin/veroeffentlichungen_beschluesse /2004/2004_12_16-Standards-Lehrerbildung-Bildungswissen schaften.pdf

Landrum, T. J., Cook, B. G., Tankersley, M. \& Fitzgerald, S. (2002). Teacher perceptions of the trustworthiness, usability, and accessibility of information from different sources. Remedial and Special Education, 23(1), 42 -48. https://doi.org/10.1177/0741932 50202300106

List, A. \& Du, H. (2020). Reasoning beyond history: Examining students' strategy use when completing a multiple text task addressing a controversial topic in education. Reading \& Writing [advanced online publication]. https://doi.org/10.1007/s11145020-10095-5

Menz, C., Spinath, B. \& Seifried, E. (2021). Where do pre-service teachers' educational psychological misconceptions come from? The roles of anecdotal versus scientific evidence. Zeitschrift für Pädagogische Psychologie, 35(2 - 3), 143 - 156. https:// doi.org/10.1024/1010-0652/a000299

Merk, S., Rosman, T., Rueß, J., Syring, M. \& Schneider, J. (2017). Preservice teachers' perceived value of general pedagogical knowledge for practice: Relations with epistemic beliefs and source beliefs. PloS ONE, 12(9), e0184971. https://doi.org/10. 1371/journal.pone.0184971

Niemi, H. (2008). Research-based teacher education for teachers' lifelong learning. Lifelong Learning in Europe, 13(1), 61 - 69.

Perfetti, C. A., Rouet, J. F. \& Britt, M. A. (1999). Toward a theory of documents representation. In H. Van Oostendorp \& S. R. Goldman (Eds.), The construction of mental representation during reading (pp. 99 -122). Mahwah, NJ: Erlbaum.

Ramos, K. D., Schafer, S. \& Tracz, S. M. (2003). Validation of the Fresno test of competence in evidence based medicine. BMJ: British Medical Journal, 326, 319 - 321. https://doi.org/10.1136/ bmj.326.7384.319

Ratcliffe, M., Bartholomew, H., Hames, V., Hind, A., Leach, J., Millar, R. \& Osborne, J. (2005). Evidence-based practice in science education: The researcher-user interface. Research Papers in Education,20(2),169-186.https://doi.org/10.1080/02671520500078036

Rousseau, D. M. \& Gunia, B. C. (2016). Evidence-based practice: The psychology of EBP implementation. Annual Review of Psychology, 67, 667-692. https://doi.org/10.1146/annurev-psych$122414-033336$

Rubin, A. (2008). Practitioner's guide to using research for evidencebased practice. Hoboken, N.J.: Wiley.

Seidel, T., Knogler, M., Mok, S. Y., Hetmanek, A., Bauer, J., Vogel, F., Bannert, M. \& Lankes, E.-M. (2017). Forschung fördert Bildung: Das Clearing House Unterricht [Research fosters education: The Clearing House Unterricht.]. Journal für LehrerInnenbildung, 17, 23 - 28.

Slavin, R. E. (2002). Evidence-based education policies: transforming educational practice and research. Educational Researcher, 31(7), 15 - 21. https://doi.org/10.3102/0013189X031007015

Stark, R. (2017). Probleme evidenzbasierter bzw. -orientierter pädagogischer Praxis [Problems of evidence-based or rather evi- dence-oriented educational practice]. Zeitschrift für Pädagogische Psychologie, 31(2), 99-110. https://doi.org/10.1024/ 1010-0652/a000201

Tabak, I. (2016). Functional scientific literacy: Seeing the science within the words and across the web. In L. Corno \& E. M. Anderman (Eds.), Handbook of Educational Psychology (3rd ed., pp. 269 - 280). New York, NY: Routledge.

Thomm, E., Gold, B., Betsch, T. \& Bauer, J. (2021). When preservice teachers' prior beliefs contradict evidence from educational research. British Journal of Educational Psychology, e12407. https:// doi.org/10.1111/bjep.12407

Thomm, E., Sälzer, C., Prenzel, M. \& Bauer, J. (2021). Predictors of teachers' appreciation of evidence-based practice and educational research findings. Zeitschrift für Pädagogische Psychologie, 35(2-3), 173 -184. https://doi.org/10.1024/1010-0652/ a000301

Trempler, K., Hetmanek, A., Wecker, C., Kiesewetter, J., Wermelt, M, Fischer, M., Fischer, F. \& Gräsel, C. (2015). Nutzung von Evidenz im Bildungsbereich. Validierung eines Instruments zur Erfassung von Kompetenzen der Informationswahl und Bewertung von Studien [Using evidence in education. Validating an instrument for measuring competencies of information selection and evaluation of research studies]. Zeitschrift für Pädagogik, 61, 144-166.

van Schaik, P., Volman, M., Admiraal, W. \& Schenke, W. (2018). Barriers and conditions for teachers' utilisation of academic knowledge. International Journal of Educational Research, 90, 50 - 63. https://doi.org/10.1016/j.ijer.2018.05.003

Wenglein, S., Bauer, J., Heininger, S. \& Prenzel, M. (2015). Kompetenz angehender Lehrkräfte zum Argumentieren mit Evidenz: Erhöht ein Training von Heuristiken die Argumentationsqualität? [Pre-service teachers' evidence-based argumentation competence: Can a training of heuristics improve argumentative quality?]. Unterrichtswissenschaft, 43(3), 209 - 224.

Williams, D. \& Coles, L. (2007). Teachers' approaches to finding and using research evidence: An information literacy perspective. Educational Research, 49(2), 185-206. https://doi.org/10. 1080/00131880701369719

Wineburg, S. S. (1991). Historical problem solving: A study of the cognitive processes used in the evaluation of documentary and pictorial evidence. Journal of Educational Psychology, 83, 73 - 87. https://doi.org/10.1037/0022-0663.83.1.73

Zimmermann, M. \& Mayweg-Paus, E. (2021). The role of collaborative argumentation in future teachers' selection of online information. Zeitschrift für Pädagogische Psychologie, 35(2-3), 185 - 198. https://doi.org/10.1024/1010-0652/a000307

\section{History}

Published online April 27, 2021

\section{Acknowledgments}

We would like to thank the editors of the journal and their team for supporting us in the realization of this special issue. Many thanks also go to Leila Ferguson and Frank Fischer for their willingness to discuss the five empirical studies and to all the reviewers for reading and commenting thoughtfully on the manuscripts. We greatly appreciate their efforts, particularly in the time of the COVID19-pandemic that has urged us more than ever to carefully consider our choices of information sources.

\section{Eva Thomm}

University of Erfurt

Faculty of Education

Nordhaeusser Str. 63

99089 Erfurt

Germany

eva.thomm@uni-erfurt.de 